\title{
NOTES ON LESQUERELLA (CRUCIFERAF) IN MEXICO
}

\author{
Reed C. Rollins.
}

Most of the twelve species of Lesquerella ordinarily attributed to México are found in the northeastern part of the country (Payson, 1922; Rollins, 1940, 1941, 1955). Two species, L. Palmeri Wats. and L. peninsularis Wiggins, oceur in Baja California. Otherwise the genus is concentrated in the mountain, foothills, and high plains of the states of Coahuila, Nuevo León, San Luis Potosí, Zacatecas and Guanajuato, with one species, L. argentea (Schaner) Wats., found in Hidalgo and another, L. pueblensis Payson, occurring in Puebla and Oaxaca.

The limestone soils that abound in the Sierra Madre Oriental provide ideal habitats for Lesquerella and the gemus is considerably developed more or less throughout the length of this mountain chain. The physiographic complexity of the eastern Sierra provides an ample number of different biological niches for speciation in Lesquerella to have been reasonably intense in the area. How many species of Lesquerella exist in México is still not known because many parts of the country where this genus is likely to oceur have not been adequately explored. Nearly every collection of specimens of any size made in an appropriate place has undescribed species in it. It is the purpose of the present paper to pui on record two such undescribed species which have come to my attention in connection with a broader study of the genus Lesquerella.

\section{Lesquerella Mirandiana Rollins, sp. nov.}

Perennial, densely pubescent with stellate trichomes; stems several from a thickened caudex, arising laterally below terminal rosette of leaves, decumbent to erect, simple, densely pubescent with appressed stellate trichomes, $1.5-4 \mathrm{dm}$. long; basal leaves petiolate, oblanceolate, obtuse, entire or rarely somewhat sinuate. densely pubescent with appressed stellae, $2-5 \mathrm{~cm}$. long. $5-10 \mathrm{~mm}$. wide forming a terminal rosette; cauline leaves petiolate to sessile, entire to barely and sparsely dentate, oblanceolate to nearly linear, densely pubescent, lower cauline leaves petiolate, petiole gradually reduced upward, the uper cauline leaves sessile and with a euneate base, $1-2 \mathrm{~cm}$. long, 4-10 $\mathrm{mm}$. wide, sepals densely pubescent, oblong, nonsaccate, $3-4 \mathrm{~mm}$. long; petals spatulate, light lavender to whitish; filaments not dilated at base; infructescence lax. often somewhat elongated, $5-15 \mathrm{~cm}$. long; pedicels recurved to somewhat sigmoid, densely pubescent, $5-8 \mathrm{~mm}$. long; siliques sessile, nearly 
globose, at right angles to rachis, to pendant or rarely somewhat asceding glabrous, on exterior and interior, $5-7 \mathrm{~mm}$. in diameter; septum entire; styles slender, 2.5-3.5 mm. long; ovules 8-10 in each loculus, funiculi slender, attached to septum by at leas half their lengths, extending nearly to base of replum on each side; seeds brown, plump, compressed parallel to the flattened part of the cotyledons, wingless, orbicular, ca $1.5 \mathrm{~mm}$. in diameter; cotyledons accumbent. Plate I, fig. $2,2 \mathrm{~A}, 2 \mathrm{~B}$.

Herba perennis; caulibus decumbentibus vel raro erectis simplicibus $1.5-4 \mathrm{dm}$. longis; foliis indumento argenteo-stellato tectis; radicalibus petiolatis integris vel raro plus minusve sinuatis obtusis $2-5 \mathrm{~cm}$. longis, 5 - $10 \mathrm{~mm}$. latis; foliis caulinis petiolatis vel sessilibus ad basi cuneatis oblanceolatis vel linearibus integris vel raro sparse dentatis $1-2 \mathrm{~cm}$. longis; petalis spathulatis purpureis vel albidis; infructescentiis elongatis laxis; pedicellis recurvatis pubescentibus 5-8 longis; siliquis globosis glabris sessilibus, circiter $5-7 \mathrm{~mm}$. diametro; loculis 8 - 10 ovulatis; stylis $2.5-3.5 \mathrm{~mm}$. longis; funiculis septo adnatis, seminibus inmarginatis brunneis; cotyledonibus accumbentibus.

Type in the Gray Herbarium, with following collection data: common among shrubs of upper cañons, flower color light lavender; Cañon de los Capulines above San Enrique, Hacienda San José de Raíces, Municipio de Derrumbadero, Nuevo León, México, Aug. 6, 1935, C. H. Mueller 2412.

Other specimens examined -México-- Nuevo León: near Ojo de Agua, foot of Cerro de Potosí, July 14, 1945. A. J. Sharp 45730 (GH); San Franciseo Canyon, about 15 miles southwest of Pueblo Galeana, Sierra Madre Oriental, May 9, 1934, C. H. and H. T. Mueller $279(\mathrm{GH})$; same locality, May 10, 1934, C. H. and H. T. Mueller 291 (GH). San Luis Potosí: Sierra de Catorce, F. Rodríguez 1 (US).

Lesquerella Mirandiana is related to $\mathbf{L}$. Schaffneri by virtue of the similarities of overall growth features, flower size, flower color, number of ovules, pedicel position and glabrous siliques. However, there is a consistent pattern of differences between the two species which provides evidence for their being separate natural taxa. L. Mirandiana has shorter and stouter pedicels that are mostly recurved and not sigmoid as in L. Schaffneri. An exception is C. H. and M. T. Mueller 291, which has somewhat sigmoid pedicels. Of greater significance, is the silique size, which is 5-7 mm. in diameter in L. Mirandiana, but only $3-4 \mathrm{~mm}$. in L. Schaffneri. Also the siliques are substipitate in the latter species but completely sessile in L. Mirandiana. Another point of difference is in the behavior of the terminal bud. In $\mathbf{L}$. Schaffneri, the terminal bud or- 
dinarily gives rise to a fertile shoot. On the other hand, in L. Mirandiana, the terminal bud gives rise to a series of leaves which form a sterile rosette, the fertile branches arising laterally from the leaf axils. Finally, there is a noticeable difference between the two speeies in the form of the trichome that makes up the indument. The trichomes of $L$. Schnafferi have many simple rays that are fused a!most to the tips into a peltate scale, whereas those of $\mathbf{L}$. Mirandiana have the rays more or less free except toward the base, where they become fused into a eireular dise (ef. Plate I, fig. 2A).

Lesquerella mexicana Rollins, sp. nov.

Perennial, silvery pubescent, trichomes small and stellate with numerous fused rays; stems slender, erect to nearly prostrate, simple, $6-15 \mathrm{~cm}$. long; densely pubescent; basal leaves potiolate, broadly spatulate to oblancetolate, obtuse, sinuate dentate to entire, silvery pubescent with a dense covering of small scale-like trichomes, $3-6 \mathrm{~cm}$. long, $6-10 \mathrm{~mm}$. wide, petiole slender; cauline leaves few, linear-oblanceolate, cuneate at base. entire, $6-10 \mathrm{~mm}$. long; flowers small; sepals linear oblong, ca. $3 \mathrm{~mm}$. long, densely pubescent on the outer side; petals light lavendor, linoulate, not differentiated into blade and claw, $4-5 \mathrm{~mm}$. long, 1.5-2 mm. wide; infructescence elongated, $4-7 \mathrm{~cm}$. long; pedicels slender, weakly sigmoid to slightly recurved, $8-12 \mathrm{~mm}$. long, densely pubescent: siliques globose, stipitate, glabrous on exterior and interior, horizontal to somewhat erect, $3-4 \mathrm{~mm}$. in diameter; stipes ca. $0.5 \mathrm{~mm}$. long; styles slender, $2-2.5 \mathrm{~mm}$. long; septum entire; ovules $2-3$ in each loculus; funiculi stout, attached to septum only at base; seeds brown, wingless, plump, compressed parallel to cotyledons, nearly orbicular, ca. $2 \mathrm{~mm}$. in diameter; cotyledons accumbent. Plate I, fig. 1, 1A, $1 \mathrm{~B}$ and $1 \mathrm{C}$.

Herba perennis argenteto-stellato pubescens; caulibus simplicibus erectis vel decumbentibus dense pubescentibus $6-15 \mathrm{~cm}$. longis: foliis radicalibus peticlatis late spathulatis vel oblanceolatis obtusis sinuatis vel integris argenteo-stellato pubescentibus $3-6 \mathrm{~cm}$. longis, $6-10 \mathrm{~mm}$. lonlatis; foliis caulinis cuneatis lineari-oblanceolatis integris $6-10 \mathrm{~mm}$. longis; sepalis lineari-oblongis ca. $3 \mathrm{~mm}$. longis; petalis lingulatis purpureis $4-5 \mathrm{~mm}$. lingis, $1.5-2 \mathrm{~mm}$. latis; pedic ?llis sigmoideis vel recurvatis 8 - $12 \mathrm{~mm}$. longis; siliquis globosis glabris stipitatis $3-4 \mathrm{~mm}$. diametro; loculis 2 - 3 ovulatis; stylis tenuis $2-2.5 \mathrm{~mm}$. longis; seminibus immarginatis orbicularibus brunneis ca. $2 \mathrm{~mm}$. diametro; cotyledonibus accumbentibus.

Type in the Gray Herbarium, collected at a pass in the hills, 43 miles 
south of Monclova, Coahuila, México, Aug. 14, 1948, Kenoyer and Crum 2625.

If the number of ovules produced is a leading criterion of relationship, L. mexicana is most closely related to $\mathbf{L}$. pueblensis, for in both species the ovule number is two to three per loculus. In other respects, too, these species are somewhat similar. For example, both are very silvery from the extremely dense encrusting of the foliage by minute overlapping stellate trichomes. The siliques are about the same size and the basal leaves have very slender petioles in both species. L. mexicana differs from $\mathrm{L}$. pueblensis in having stipitate instead of sessile siliques, smaller trichomes with the rays fused all the way to the tip (cf. Plate I, fig. 1A) instead of somewhat larger trichomes with the outer half of the rays free, as in L. pueblensis. Furthermore, the basal leaves tend to be sinuate dentate in $\mathbf{L}$. mexicana while they are entire in $\mathbf{L}$ pueblensis. The cauline leaves are well developed and overlapping in the latter species, there being up to fifteen or so per stem, but in L. mexicana, there are only three or four cauline leaves per stem and these are apt to be quite reduced. - Gray Herbarium of Harvard University.

\section{LITERATURE CITED}

PAYSON, EDWIN B. 1922.-A Monograph of the Genus Lesquerella. Ann. Mo. Bot. Gard. 8:103-236.

ROLLINS, REED C. 1940.--Notes on Some Crucifers of Texas, México and South America. Jour. Arn. Arb. 21:392-396.

- -1941 - Some New or Noteworthy North American Crucifers. Contrib. Dudley Herb. 3:174-184. - ora 57:241-264. 


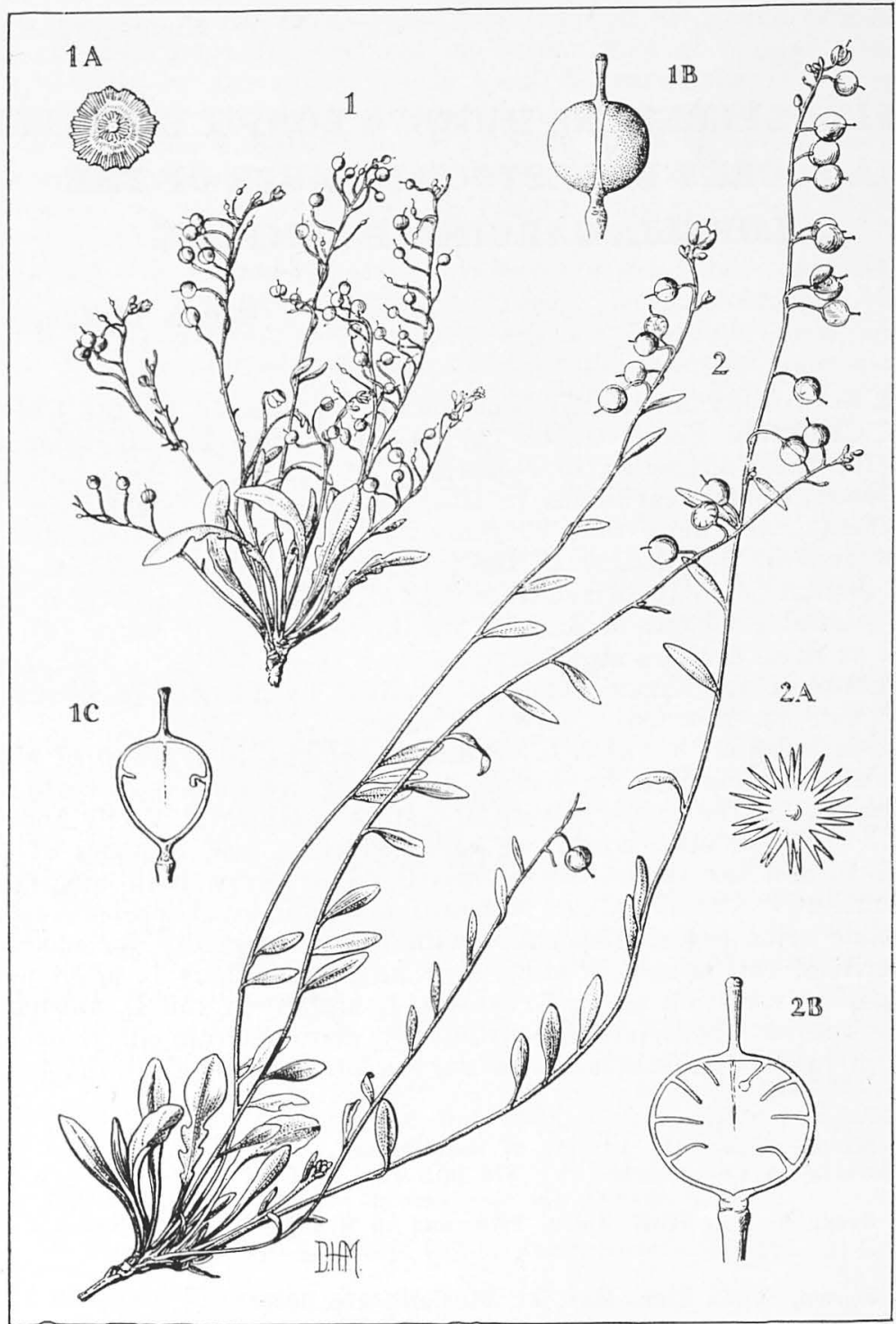

Lesquerella. 1, L. mexicana $\times 1 / 2 ; 1 \mathrm{~A}$, trichome $\times 25 ; 1 \mathrm{~B}$, silique $\times 3 ; 1 \mathrm{C}$, replum $\times 3 ; 2$, L. Mirandiana $\times 1 / 2 ; 2$ A, trichome $\times 25 ; 2 \mathrm{~B}$, replum $\times 3$. (Drawings by Dorothy H. Marsh). 